The following is the programme of the chief proceedings :

September 5 .

Opening of the Bureau.

Meeting of the International Council.

Opening of the Exhibition.

Opening of the Congress by Her Majesty the Queen-Mother.

Discussion of the Reports on methods of examination, standardisation and others.

September 6.

Demonstration Meeting.

Symposium on Glaucoma.

September 7.

Papers.

September 9.

Symposium on Trachoma.

Papers.

September 10.

Papers.

September 11.

Transference of Congress to Scheveningen. 
OXford Ophthalmological Congress

September 12.

Papers.

Symposium on supra-sellar tumours.

Banquet.

September 13.

Papers.

General Meeting.

Closing Session.

Reception by the Municipality of the Hague.

\section{OXFORD OPHTHALMOLOGICAL CONGRESS XIXTH ANNUAL MEETING}

THE XIXth Annual Meeting of the Oxford Ophthalmological Congress was held at Oxford on July 4, 5 and 6 last.

Members met informally at dinner on the 3rd in the Hall of Keble College, which had again offered its hospitality as in former years. The advantages which are gained by the all too short stay in the College, where each member is assigned rooms and becomes for the time being a student again, are quite one of the features of th's successful annual gathering of ophthalmic surgeons, which was founded by the late Robert Doyne nearly twenty years ago. The proceedings of the Congress were held in the Department of Human Anatomy of the University, kindly lent for the purpose by Professor Arthur Thomson, to whom the Congress is under a deep debt of gratitude. In addition to the Scientific Museums, a Commercial Museum was on view in which fourteen well known firms of ophthalmic instrument makers exhibited the latest forms of apparatus and instruments.

The Master this year is Mr. Bernard Cridland, who has been Secretary for the past sixteen years. This appointment has been received with high approval by the members as it is common knowledge amongst them that one of the great factors in the continuous success of the Congress has been the work put into the organisation and arrangements of the meetings by Mr. BERNARD C.RIDLAND. 